\section{Bilateral Temporal Bone Xanthomas in Type II Hypercholesterolemia}

\section{Tip 2 Hiperkolesterolemide Bilateral Temporal Kemik Ksantoması}

\begin{abstract}
We present a very rare case of intracranial xanthoma with bilateral temporal bone involvement. The lesion caused destruction and remodelling in mastoid air cells. On the right side, cerebellar compression was obvious. The patient was operated on the symptomatic side and the lesion was totally removed.

KEYWORDS: Bilateral, Hypercholesterolemia, Intracranial, Temporal bone, Xanthoma

\section{ÖZ}

Bilateral temporal kemik tutulumu olan ve çok nadir olarak görülen intrakranyal ksantoma vakası sunulmaktadır. Çocukluk çağında Tip 2 hiperkolesterolemi teşhisi almış 23 yaşındaki erkek hasta, iki yıldır olan ve giderek şiddeti artan baş ağrısı ve ataksi şikayeti ile başvurdu. Klinik muayenesinde serebeller ataksi mevcuttu ve Romberg testi pozitifti ancak ekstremitelerinde güç kaybı ve işitme kaybı yoktu. Her iki dirseğinde, dizlerinde ve parmaklarının ekstensör yüzeylerinde ksantomaları mevcuttu. Lezyon mastoid hava hücrelerinde destrüksiyona ve yeniden şekillenmeye neden olmuştur. Sağ tarafta serebellar kompresyon mevcuttu. Hasta semptomatik taraftan opere edilmiş ve lezyon tamamen çıkarılmıştır.
\end{abstract}

ANAHTAR SÖZCÜKLER: Çift taraflı, Hiperkolesterolemi, İntrakranyal, Temporal kemik, Ksantoma

\section{Cezmi TURK ${ }^{1}$ \\ Burcak BILGINER ${ }^{2}$ \\ Kemal BENLI ${ }^{3}$ \\ Kivilcim YAVUZ ${ }^{4}$ \\ Arzu SAGLAM ${ }^{5}$ \\ Ibrahim M. ZIYAL ${ }^{6}$}

1,2,3,6 Hacettepe University, School of Medicine, Department of Neurosurgery, Ankara, Turkey

4 Hacettepe University, School of Medicine, Department of Radiology, Ankara, Turkey

5 Hacettepe University, School of Medicine, Department of Pathology, Ankara, Turkey

Received : 05.01.2010

Accepted : 25.01.2010

Correspondence address: Ibrahim M. ZIYAL

Hacettepe University, School of Medicine

Department of Neurosurgery,

Sihhiye, Ankara, Turkey

Phone : +90 3123051715

Fax : +90312311 1131

E-mail : ibrahimziyal@yahoo.com 


\section{INTRODUCTION}

Xanthomas are benign lesions which may originate from abnormal deposition of cholesterol and lipid into tissues leading to inflammatory cell infiltration (3). They affect various parts of the body; skin, tendons, flat bones, cerebral paranchym etc. (5). Intracranial xanthomas are rare entities and they may present with different symptoms depending on direct compression onto neural structures or on increased intracranial pressure (4). As far as we know, this is the first case of an intracranial xanthoma with bilateral involvement of temporal bones.

\section{CASE REPORT}

A-23-year-old male admitted with complaints of progressive headache and ataxia persisting since two years. Clinical examination showed cerebellar ataxia, positive Romberg test without any extremity weakness and hearing loss. Several xanthomas were noted on elbows, knees and over extensor surface of fingers. The patient had type II hypercholesterolemia diagnosed in childhood. The cholesterol and LDL levels were over normal ranges, $467 \mathrm{mg} \backslash \mathrm{dl}$ and 424 $\mathrm{mg} \backslash \mathrm{dl}$, respectively. Cranial $\mathrm{X}$ ray and computed tomographic (CT) scans showed osteolytic lesions affecting bilateral temporal regions and destructing mastoid air cells (Figure 1A,B). On the right side, magnetic resonance imaging (MRI) scans showed heterogenous cystic lesion, containing lipid. There was no diffusion restriction on diffusion weighted images on either side (Figure 1C,D). The patient was operated on the right temporal region. After turning the skin flap, the xanthoma was visible. The lesion was lobulated, yellowish in color, filling all mastoid air cells and was destructing the temporal bone all the way down to the dura. The lesion was removed totally (Figure 2A). On histopathological examination a destructive infiltrate composed of foamy macrophages with interspersed foreign body giant cells and cholesterol clefts was demonstrated (Figure 2B).

\section{DISCUSSION}

Intracranial xanthomas are very rare entities. They generally originate from hyperlipidemic and hypercholesterolemic diseases $(1,2)$. They are also reported in non-hyperlipidemic states like histiocytosis, fibrous xanthomas, multicystic granulomatosis (6). Extraaxial xanthomas are generally well circumscribed lesion that may cause bony destruction and remodelling. MRI findings

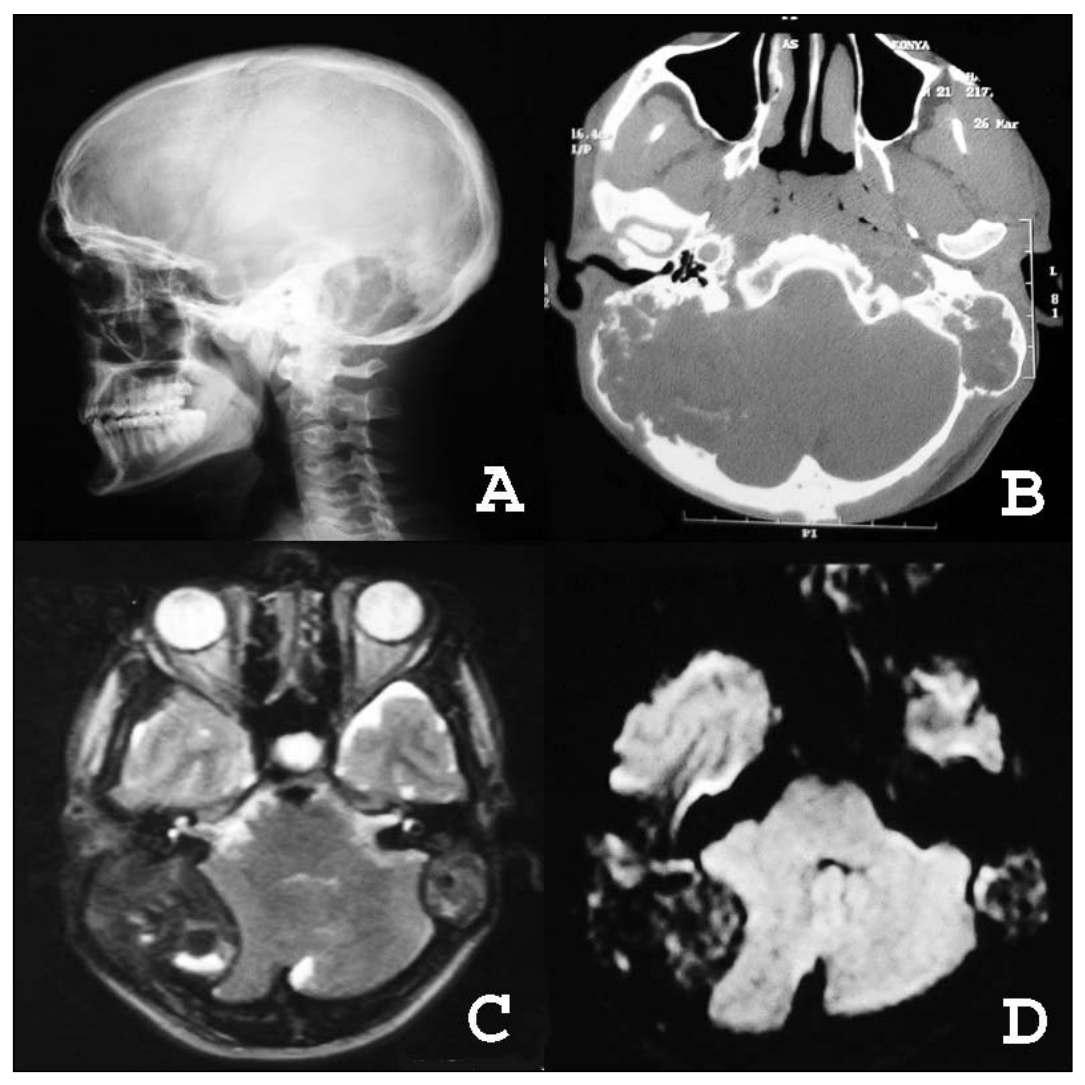

Figure 1: Osteolytic nature of the xanthoma is obvious on right lateral $X$ ray $(A)$. The $C T$ scan shows destruction of bilateral mastoid air cells on both temporal bones. Internal tabula of the temporal bone is also destructed on the right side $(\boldsymbol{B})$. Preoperative T2 weighed MRI scans show bilateral lesions affecting the temporal bones. On the right side, cerebellar compression is obvious (C). On diffusion weighted image, there is hypointensity on both temporal regions with no restriction in diffusion (D). 




Figure 2: Postoperative T2 weighted MR image of the patient revealed removal of the xanthoma on the right side $(A)$. HEE photomicrograph of the xanthomatous infiltrate demonstrated the histopathological specimen characterized by foamy macrophages, foreign body giant cells and cholesterol clefts (original magnification $x 100)(B)$.

reflect its lipid content, with heterogenous apperance being hyperintens or isointens on T1 weighted images and hypointens on T2 weighted images. There is generally neither restriction in diffusion scans nor significant contrast enhancement (4). In this location, the xanthomas should also be differentiated from cholesteatomas, cholesterol granulomas and epidermoid tumors of the temporal bone (4).

In our case, there was bilateral involvement of temporal bones. The right side was dominant and symptomatic. The symptoms relieved after removal of the lesion. General radiological apperance of the case was similar to the literature. During the surgery, this cystic component was drained. The fluid was similar to mucopurulent discharge drained from ear reported by Basavaraj et al.(3). This may correlate with degeneration of the xanthoma. In neurosurgical literature, unilateral temporal bone involvement was reported before $(3,6)$. However, bilateral involvement of temporal bones was not yet reported. The treatment strategy is generally total removal of the symptomatic intracranial xanthoma. We operated on this case because there was compression on the cerebellum correlating with clinical findings. The medications like resins, niacin, statins together with dietary measures may also be useful at lowering serum cholesterol levels. In selected cases, plasmapheresis may be preferred as adjunct to treatment strategy.

In conclusion, xanthomas may occupy the cranial bones bilaterally. Symptomatic ones should be removed preferentially and radically.

\section{REFERENCES}

1. Akazawa S, Ikeda Y, Toyama K, Miyake S, Takamori M, Nagataki S. Familial type 2a hyperlipoproteinemia associated with a huge intracranial xanthoma. Arch Neurol 41: 793- 794, 1984

2. Algoed L, Caemaert J, Achten E, Aken JV, Reuck JD. A large intracranial xanthoma in familial hypercholesterolemia. Clin Neurol Neurosurg 96: 79-82, 1996

3. Basavaraj AB, Jadhav $S$, Dhadwad J. Familial hypercholesterolemia presenting as intracranial xanthoma. J Am Coll Cardio 54:330-332, 2006

4. Bonhomme GR, Loevner LA, Yen DM, Deems DA, Bigelow DC, Mirza N Extensive intracranial xanthoma associated with type 2 hyperlipidemia. Am J Neuroradiol 21:353-355, 2000

5. Hwang YJ, Hur G, Cha SJ, Kim YH, Kim SY, Kim MK. Intracranial xanthoma: Long term follow up MR findings. Am J Neuroradiol 27: 423-426, 2006

6. Kuroiwa T, Ohta T, Tsutsumi A. Xanthoma of the temporal bone: Case report. Neurosurgery 46(4): 996-998, 2000 